\title{
Antitumor agents 294. Novel E-ring-modified camptothecin-4 $\beta$ - anilino-4'-O-demethylepipodophyllotoxin conjugates as DNA topoisomerase I inhibitors and cytotoxic agents
}

\author{
Deyong Ye ${ }^{a}$, Qian Shi ${ }^{a},{ }^{*}$, Chung-Hang Leung ${ }^{b, \dagger}$, Seung-Whan Kim ${ }^{b, \dagger}$, Shin-Young Park ${ }^{b}$, \\ Elizabeth A. Gullen ${ }^{b}$, Zao Li Jiang ${ }^{b}$, Hao Zhu ${ }^{c}$, Susan L. Morris-Natschke ${ }^{a}$, Yung-Chi \\ Cheng ${ }^{b,{ }^{*}}, \neq$, and Kuo-Hsiung Lee ${ }^{a, d},{ }^{*}$ \\ aNatural Products Research Laboratories, UNC Eshelman School of Pharmacy, University of \\ North Carolina at Chapel Hill, Chapel Hill, North Carolina 27599-7568 \\ bDepartment of Pharmacology, Yale University School of Medicine, New Haven, Connecticut \\ 06520 \\ 'Department of Chemistry, The Rutgers Center for Computational and Integrative Biology, \\ Rutgers University, 315 Penn St., Camden, NJ 08102 \\ ${ }^{\mathrm{d} C h i n e s e ~ M e d i c i n e ~ R e s e a r c h ~ a n d ~ D e v e l o p m e n t ~ C e n t e r, ~ C h i n a ~ M e d i c a l ~ U n i v e r s i t y ~ a n d ~ H o s p i t a l, ~}$ \\ Taichung, Taiwan
}

\begin{abstract}
Two conjugates (1 and $\mathbf{2}$ ) of camptothecin (CPT) and $4 \beta$-anilino- $4^{\prime}-O$ -

demethylepipodophyllotoxin were previously shown to exert antitumor activity through inhibition of topoisomerase I (topo I). In this current study, two novel conjugates (1E and $\mathbf{2 E}$ ) with an open

E-ring in the CPT moiety were first synthesized and evaluated for biological activity in comparison with their intact E-ring congeners. This novel class of CPT derivatives exhibits its antitumor effect against CPT-sensitive and -resistant cells, in part, by inhibiting topo I-linked DNA (TLD) religation. An intact E-ring was not essential for the inhibition of TLD religation, although conjugates with an open E-ring were less potent than the closed ring analogs. This lower religation potency resulted in decreased formation of protein-linked DNA breaks (PLDBs), and hence, less cell growth inhibition. In addition to their impact on topo I, conjugates $\mathbf{1 E}, \mathbf{2}$, and $\mathbf{2 E}$ exhibited a minor inhibitory effect on topo II-induced DNA cleavage. The novel structures of $\mathbf{1 E}$ and $2 \mathbf{E}$ may present scaffolds for further development of dual function topo I and II inhibitors with improved pharmacological profiles and physicochemical properties.
\end{abstract}

\section{Keywords}

Topoisomerase; cytotoxicity; camptothecin (CPT); etoposide (VP-16); epipodophyllotoxin; conjugates

\footnotetext{
(C) 2012 Elsevier Ltd. All rights reserved.

*Corresponding authors: Q.S.: Tel: 919-843-6325; qshi1@email.unc.edu K.H.L.: Tel: 919-962-0066; Fax: 919-966-3893; khlee@unc.edu; Y.C.C. Tel: 1-203-785-7118; Fax: 1-203-785-7129; yccheng@yale.edu.

$\dagger$ Leung $\mathrm{CH}$ and Kim SW contributed equally to this work

‡Fellow of the National Foundation for Cancer Research

Publisher's Disclaimer: This is a PDF file of an unedited manuscript that has been accepted for publication. As a service to our customers we are providing this early version of the manuscript. The manuscript will undergo copyediting, typesetting, and review of the resulting proof before it is published in its final citable form. Please note that during the production process errors may be discovered which could affect the content, and all legal disclaimers that apply to the journal pertain.
} 


\section{Introduction}

Camptothecin (CPT), an alkaloid isolated from the Chinese bush Camptotheca acuminata (Nyssaceae) by Wall and co-workers in $1966,{ }^{1}$ was the first identified specific inhibitor of DNA topoisomerase I. ${ }^{2}$ Topoisomerase I (Topo I) cuts one strand of double-stranded DNA, relaxes the strands, and then re-anneals the strands. ${ }^{3} \mathrm{CPT}$ exhibits its cytotoxic activity by stabilizing the topo I-DNA complex, which prevents religation and causes single stranded breaks, a process that eventually leads to cell death. ${ }^{4}$ Several CPT-derivatives, including topotecan and irinotecan (CPT-11), ${ }^{5-6}$ have been used clinically for the treatment of colorectal, ovarian and small cell lung cancers. However, the development of resistance to these compounds is still a critical clinical problem.

CPT-resistance can result from various cellular events, including inadequate accumulation of the drug, alteration of topo I resulting in decreased formation of protein-linked DNA breaks (PLDB), and alterations in the cellular response to the topo I-CPT interaction. ${ }^{7}$ Furthermore, the acquisition of resistance to topo I inhibitors is often accompanied by a concomitant rise in the level of topo II expression and vice versa, which leads to the failure of clinical therapies.

Topoisomerase inhibitors with dual target specificity could possibly overcome CPTresistance. Dual target inhibitors would likely retain cytotoxic activity when resistance was acquired due to alteration of only one drug target. However, the physical combination of CPT with drugs such as amsacrine and doxorubicin, which also interfere with DNA topoisomerases, often caused antagonistic cytotoxic effects rather than synergistic activity. ${ }^{8-11}$ In this regards, a single compound able to inhibit both topo I and topo II may present the advantage of improving anti-topoisomerase activity, with reduced or avoiding adversities respect to the combination of two inhibitors. Many efforts have been made to discover and develop a powerful "magic bullet" targeted to both enzymes, ${ }^{12,13}$ such as Tafluposide, ${ }^{14}$ Batracylin, ${ }^{15}$ and other synthetic or natural products. But, to date, none has been used in the clinic. Conjugation of two drug molecules through covalent chemical bonds to generate a single drug molecule with dual functional topoisomerase inhibitory activity has not been fully explored. Chemical conjugation of CPT with another chemotherapeutic topoisomerase inhibitor could still be a relevant approach to generate a new monomolecule with possible dual target specificity. The mechanism of action and metabolism profile of a conjugate (as a monomolecule) may be independent from those of the parent compounds alone or the simultaneous physical (rather than chemical) combination of the two parents. We hope through this strategy to develop new drug candidates potentially inhibiting proliferation of CPT resistant cells.

Etoposide (VP-16), a prototypical epipodophyllotoxin, is another widely used anticancer drug, which functions as a topoisomerase II inhibitor. Topoisomerase II (topo II) incises double stranded DNA to facilitate the passage of an intact duplex through the gap before rejoining the cut DNA. ${ }^{16}$ Etoposide inhibits cell growth by stabilizing the topo II-DNA complex, resulting in double-stranded DNA breaks and subsequent cell death. ${ }^{17,18}$

Previously, numerous epipodophyllotoxin derivatives were synthesized and reported as active topo II inhibitors. ${ }^{19,20}$ The design of compounds that could also interact with topo II, in addition to topo I, was attempted through the chemical combination of topo I and topo II inhibitors. Two conjugates (1 and $\mathbf{2})$ in which the topo I inhibitor camptothecin and the topo II inhibitor $4 \beta$-anilino- $4^{\prime}$-O-demethylepipodophyllotoxin were linked via a covalent imine bond were synthesized and evaluated for biochemical and biological activities. ${ }^{21,22}$

In earlier studies, the conjugates $\mathbf{1}$ and $\mathbf{2}$ displayed a broad spectrum of cytotoxic activity against drug-resistant cell lines. ${ }^{21,22}$ Both compounds inhibited topo I, but only $\mathbf{2}$ was active 
against topo II, although at a higher concentration $(100 \mu \mathrm{M})$. Both compounds induced PLDB in KB cells and had similar in vitro cytotoxicity. These results warrant the further molecular design of CPT-epipodophyllotoxin conjugates as antitumor agents.

Prior structure-activity relationship (SAR) studies on CPT-derivatives indicated that the lactone E-ring is essential for both antitumor and topo I inhibitory activities. The 20hydroxy group of CPT's intact lactone E-ring forms a hydrogen bond with the topo I-linked DNA (TLD) and, thus, stabilizes the complex. ${ }^{23-25}$ CPT can be rapidly inactivated through E-ring lactone reversible hydrolysis at physiological conditions, leading to an inactive water soluble carboxylate, which binds readily to human serum albumin making the compound inaccessible for cellular uptake. ${ }^{26,27}$

However, E-ring-modified ester-amide CPT-derivatives have been reported to show high potency against L1210 tumors. ${ }^{28}$ The re-conversion of these derivatives to CPT in vivo was considered to be necessary for significant activity. The isopropyl amide of a CPT open Ering analog was reported to be more stable under the experimental conditions and less likely than other amide analogs to convert to the E-ring closed lactone form (e.g., CPT) or subsequently to the hydroxy-acid (E-ring open form) ${ }^{28}$ Consequently, it might bind less readily to human serum album. Thus, the biological activity derived from the isopropyl amide analog could be considered as the open E-ring's, though it was not so reported.

In addition, CPT-epipodophyllotoxin conjugates with an open E-ring isopropyl amide moiety have not been studied, and their biological activity, especially anti-tumor activity through inhibition of topoisomerases, mechanism of action, as well as metabolism profile have not been evaluated. In this regard, in order to understand the role of the lactone E-ring in the conjugated compounds, E-ring-modified derivatives (1E and $\mathbf{2 E}$ ) of $\mathbf{1}$ and $\mathbf{2}$, respectively, were synthesized in this study and evaluated in comparison with their intact Ering congeners for cytotoxicity against $\mathrm{KB}$ cells, including resistant cells, and for inhibition of topo I and topo II.

\section{Chemistry}

The lactone E-ring conjugates $\mathbf{1}$ and $\mathbf{2}$ were synthesized as described previously, ${ }^{21}$ and were the starting materials to synthesize the open E-ring conjugates $\mathbf{1 E}$ and $\mathbf{2 E}$ (Figure 1). Conjugate 1 or $2(22.2 \mathrm{mg}, 0.262 \mathrm{mmol})$ was dissolved in $\mathrm{CHCl}_{3}(2 \mathrm{~mL})$, and then isopropylamine $(2 \mathrm{~mL})$ was added. The solution was heated to reflux for $22 \mathrm{~h}$ under nitrogen, and monitored by TLC $\left(\mathrm{CH}_{2} \mathrm{Cl}_{2}: \mathrm{MeOH}=20: 1\right)$. The solvent was removed under vacuum, and the residue was purified by silica gel chromatography $\left(\mathrm{CH}_{2} \mathrm{Cl}_{2}: \mathrm{MeOH}=100: 0\right.$ to $95: 5$ as eluent) to afford the target compounds $\mathbf{1 E}$ and $\mathbf{2 E}$, respectively, in $51-70 \%$ yield. We originally suspected that the five-membered lactone ring in the epipodophyllotoxin unit might also undergo ring-opening through amide formation. However, the major products obtained under the described conditions were the desired products. The structures of the final products were identified from spectroscopic and other analytical data. Additional physicochemical properties, such as $\log \mathrm{P}$ and $\log \mathrm{S}$ values, of the newly synthesized conjugates $1 \mathrm{E}$ and $2 \mathrm{E}$ were also evaluated to further understand the SAR of the new compounds.

\section{Results and discussion}

The effects of the new conjugates, as well as CPT and etoposide, on the growth of KB and CPT- sensitive and resistant KB cell lines were studied in a growth inhibition assay. ${ }^{22}$ As shown in Table 1, the four CPT-epipodophyllotoxin conjugates $(\mathbf{1}, \mathbf{1 E}, \mathbf{2}, \mathbf{2 E})$ were less potent than CPT against KB cells; thus, conjugation reduced potency. Interestingly, an open 
E-ring did not significantly affect the inhibitory activity, based on the observation that $\mathbf{1 E}$ and $\mathbf{2 E}$ were either as potent as or only slightly less potent than their lactone E-ring congeners, $\mathbf{1}$ and $\mathbf{2}$. Compounds $\mathbf{1}$ and $\mathbf{1 E}$, conjugated at the para-position of the aniline moiety in the epipodophyllotoxin, were more potent than $\mathbf{2}$ and $\mathbf{2 E}$, conjugated at the orthoposition.

CPT and all four CPT conjugates showed no significant cross-resistance against etoposideresistant KB-7D cells, which over-express MRP and down-regulate topo II. ${ }^{29}$ However, as expected, CPT-resistant KBCPT100 cells, which down-regulate topo I and up-regulate Xray repair cross-complementing gene I protein $(\mathrm{XRCC} 1)$, were less susceptible to $\mathrm{CPT}$ and the conjugates. [The cytotoxic effects were partially restored in CPT partial reverting KBCPT $100^{\mathrm{REV}}$ cells, because the XRCC1 over-expression is reversed. $\left.{ }^{29}\right]$ The $\mathrm{IC}_{50}$ of CPT increased by 48-fold in CPT-resistant KBCPT100 cells compared with the sensitive cells. However, the $\mathrm{IC}_{50}$ values of the conjugates increased by only 2.8- to 3.9-fold. Thus, CPTresistance was overcome by some extent by the conjugation. Also, the presence of the open E-ring did not affect the relative resistance over the parental cell line. The data suggest that topo I could be the primary molecular target of these conjugate compounds in KB cells.

After exposing KB cells to $2.5 \mu \mathrm{M}$ of test compound for $30 \mathrm{~min}$, PLDB formation was studied according to the method described previously. ${ }^{30}$ Consistent with previous findings, ${ }^{22}$ CPT induced three-fold greater PLDB compared with conjugates $\mathbf{1}$ and $\mathbf{2}$ (Figure 2). The open E-ring conjugates $\mathbf{1 E}$ and $\mathbf{2}$ showed four-fold less induction compared with their intact E-ring congeners $\mathbf{1}$ and $\mathbf{2}$, respectively. Increasing the concentration of conjugate 2E from 2.5 to $22.5 \mu \mathrm{M}$ induced a seven-fold increase in PLDB in $30 \mathrm{~min}$, which is equivalent to $60 \%$ of the PLDB induced by $2.5 \mu \mathrm{M}$ of CPT (data not shown).

DNA relaxation by topo I is a process that involves the binding of DNA to topoisomerase I, followed by cleavage and subsequent religation of the DNA. The impact of the CPT conjugates on these individual steps was investigated. A DNA duplex, which contains a 25mer (ON4) and a 14-mer (ON5), was used as the substrate (Figure 3A). The presence of two nucleotides downstream of the topo I cutting site prevents the religation process and allows the formation of a suicide TLD complex after cleavage. Similar amounts of cleavage products (measured as described previously ${ }^{31}$ ) were formed in the presence of CPT and the conjugated derivatives at a concentration of $25 \mu \mathrm{M}$ (Figure 3B). This result implies that these compounds do not interfere with the DNA cleavage activity of topo I, or by implication, with the binding of DNA to the enzyme.

Religation was then initiated by the addition of a 13-mer (ON6) to the pre-generated suicide cleavage complex (Figure 4A). The topo I religation activity was determined by measuring the amount of the religation product (a 25 -mer) formed, as previously described. ${ }^{31} \mathrm{CPT}$ inhibited TLD religation in a dose-dependent manner and reached $>95 \%$ inhibition at 25 $\mu \mathrm{M}$ (Figure 4B). In comparison, the inhibitory potencies of the intact E-ring conjugates (1 and 2) and open E-ring conjugates (1Eand 2E) were approximately 9- and 25-fold lower, respectively. Thus, an intact E-ring is not essential for the inhibition of TLD relegation, but did affect the degree of inhibition. The results from the TLD assay are consistent with those in the PLDB assay, indicating that DNA breaks induced by the conjugates could be due to inhibition of the TLD religation step.

CPT's indolizinoquinoline moiety is believed to be involved in DNA interaction, while the lactone E-ring interacts with topo I to form the TLD complex. Therefore, the E-ring lactone of CPT derivatives is commonly thought to be essential for topo I inhibition. However, in a recent study, a CPT analog with a stable five-membered E-ring ketone, not lactone, moiety retained the ability to generate topo I-mediated DNA breaks. ${ }^{25,32}$ In addition, in the present 
study, activity was inhibited by conjugates $1 \mathbf{E}$ and $\mathbf{2 E}$ bearing a modified open E-ring, although they were less potent than CPT conjugates with an intact E-ring, suggesting that an open E-ring moiety in CPT-epipodophylloxin conjugates enables to retain inhibition of topo I religation. When the religation process is completed, topo I dissociates from the DNA. Conceivably, the open E-ring CPT conjugates could have lower affinity towards the enzyme. Therefore, the conjugate-enzyme complex could dissociate more readily, and hence, the religation process could be facilitated. However, further investigation including extensive SAR study is merited and other modes of action cannot be ruled out.

To determine whether the conjugate compounds could impact topo II activity, a previously described in vitro DNA cleavage assay was performed, with etoposide (VP-16) as the positive control. ${ }^{22}$ At concentrations up to $25 \mu \mathrm{M}$, none of the conjugates induced DNA cleavage (Figure 5). However, at a high concentration $(250 \mu \mathrm{M})$, conjugates 1E, $\mathbf{2}$, and $\mathbf{2 E}$ interrupted topo II-mediated religation to different degrees. Thus, the conjugates could also interact with topo II to cause PLDB and cytotoxicity. Given that etoposied resistant cells (KB-7D) were sensitive to CPT as well as the conjugates, it is anticipated that further structural modification of these compounds could lead to the development of topoisomerase II inhibitors that can overcome resistance due to the expression of MRP.

Overall, our current and prior findings indicate that this novel class of CPTepipodophyllotoxin conjugates exhibit antitumor effects against both CPT-sensitive andresistant cells, in part, by inhibiting topo I-mediated, and possibly topo II-mediated, relegation. However, additional mechanisms are anticipated based on the assay data. For example, conjugates $\mathbf{1 E}$ and $\mathbf{2 E}$ were ten-fold and eight-fold, respectively, more potent than etoposide in suppressing KB cell growth. However, the two compounds induced significantly lower PLDB compared with etoposide. The inconsistency in the potencies between the two assays indicates that mechanism(s) independent of topo I and topo II could be involved in the growth inhibition. In addition, KBCPT100 cells were more susceptible to the conjugates than to CPT. Our previous study indicated that one factor that leads to CPTresistance in KBCPT100 cells is the up-regulation of XRCC $1,{ }^{29}$ which plays an important role in repairing single-strand breaks generated by CPT action. Based on the increased potency of the conjugates relative to CPT in this cell line, XRCC1 could be a cellular target of the conjugates. ${ }^{29}$ Further studies on mechanism of action are ongoing. Since the conjugates also showed cytotoxicity to etoposide resistant cell (KB-7D), additional mechanism could be involved and merits further investigation. Multi-target actions of these conjugates could render cancer cells less susceptible to develop resistance.

The assay results suggest that the conjugate molecule remains intact under the cell culture conditions, because the activities of the conjugates and their individual parent compounds are distinguishable. This observation is consistent with the reported stability of the imine linkage ${ }^{33}$ and previous experimental observation. ${ }^{21,22}$

Finally, related physicochemical properties, such as $\log \mathrm{P}$ and $\log \mathrm{S}$ values, were evaluated as listed in Table 1 to further understand the SAR of the conjugates. In spite of the heavy mass and limited solubility of the conjugates, other molecular properties in regard to Lipinski's five rules are still marginally acceptable. ${ }^{34}$ The E-ring open compounds $1 \mathrm{E}$ and $2 \mathrm{E}$ have slightly improved partition coefficient property $(\log \mathrm{P})$ relative to their E-ring intact counterparts (5.091 vs 5.37). These preliminary data suggest that structural modifications of the conjugates merit further investigation to generate better pharmaceutical drug-like molecules. Continuing research in the authors' laboratory includes structural modifications to generate more E-ring open CPT conjugates with various amides/esters, with different linkers, and different conjugated partners. Additional mechanism of action studies (such as 
docking experiments), as well as metabolism studies, are also ongoing. The results will be reported in due course.

\section{Conclusion}

Current preliminary study results show that CPT-epipodophyllotoxin conjugates are potent inhibitors of the growth of both CPT-sensitive and -resistant cancer cells. Conjugation of a well-known topo-I inhibitor and topo-II inhibitor ${ }^{20}$ generated a new single molecule and provided a possible approach to overcome CPT resistance to tumor cells. From the current results, one of the major mechanisms involved is the inhibition of topoisomerase I-mediated religation. The intact E-ring was critical, but not essential, for the inhibitory activity. Conjugates with an open E-ring were active, although they were less potent than the closed ring analogs. In addition to their impact on topo I, these new compounds exhibited full cytotoxic activity against both etoposide-sensitive (KB) and -resistant (KB-7D) cell proliferation, while they exhibited minor inhibitory activity against topo II-induced DNA cleavage. The findings also indicated that mechanisms independent of topo I and II could exist. The lactone E-ring has been long considered as critical to CPT's therapeutic application; however, the present study first reports that open E-ring CPTepipodophyllotoxin conjugates with an isopropyl amide group retain antitumor proliferation activity in both CPT-sensitive and resistant cells. The novel structures of $1 \mathbf{E}$ and $2 \mathbf{E}$ may serve as scaffolds for further development of topo I and II inhibitors with improved pharmacological profiles and physicochemical properties to, ultimately, overcome CPT resistance.

\section{Experimental}

\subsection{Chemistry}

Melting points (with decomposition) were determined on an Electrothermal MEL-TEMP 3.0 apparatus and are uncorrected. FT-IR was conducted on a Shimadzu IR Prestige 21 instrument. ${ }^{1} \mathrm{H}$ NMR spectra were measured on an Inova 500 spectrometer with tetramethylsilane (TMS) as the internal standard. Chemical shifts are reported in $\delta$ (ppm). Mass spectra (MS) were obtained on an Agilent 1100 series LC-MSD-Trap or PE-Sciex API-300 spectrometer. Flash column chromatography was performed on silica gel (100-200 mesh). Precoated silica gel plates (Kieselgel 60, F254, $0.25 \mathrm{~mm}$ ) were used for thin layer chromatography (TLC) analysis. CPT and etoposide were purchased from the Sigma Chemical Co. $\log P$ and $\log S$ values were calculated with.... the methods published and recommended on http://www.vcclab.org/lab/alogps

\subsection{Conjugate $1 E$}

Red-brown crystalline powder; $\mathrm{mp}>300{ }^{\circ} \mathrm{C}$ (decomp); ESI MS m/z $908.3(\mathrm{M}+1)^{+}$; FT-IR (ATR crystal plate) 3311 (broad, OH, NH), 2968, 2935 (alkyl CH), 1754 (lactone carbonyl), 1649, 1583 (amide carbonyl) cm ${ }^{-1},{ }^{1} \mathrm{H}$ NMR $\left(\mathrm{CDCl}_{3}\right): \delta 1.01\left(\mathrm{t}, J=7.0 \mathrm{~Hz}, 3 \mathrm{H}, 18^{\prime \prime \prime}-\mathrm{H}\right)$, $1.21\left(\mathrm{~d}, J=7.0 \mathrm{~Hz}, 6 \mathrm{H},\left(\mathrm{CH}_{3}\right)_{2}\right), 2.30-2.38\left(\mathrm{~m}, 2 \mathrm{H}, 19^{\prime \prime \prime}-\mathrm{H}\right), 2.94-2.96(\mathrm{~m}, 1 \mathrm{H}, 3-\mathrm{H}), 3.20$ (dd, $J=5.0,14.0 \mathrm{~Hz}, 1 \mathrm{H}, 2-\mathrm{H}), 3.80\left(\mathrm{~s}, 6 \mathrm{H}, \mathrm{OCH}_{3} \times 2\right), 4.04-4.08(\mathrm{~m}, 2 \mathrm{H}, 11-\mathrm{H}, \mathrm{NCH})$, $4.36(\mathrm{t}, J=8.5 \mathrm{~Hz}, 1 \mathrm{H}, 11-\mathrm{H}), 4.55(\mathrm{~d}, J=4.0 \mathrm{~Hz}, 1 \mathrm{H}, 1-\mathrm{H}), 4.91\left(\mathrm{~s}, 2 \mathrm{H}, 22^{\prime \prime \prime}-\mathrm{H}\right), 4.93$ (d, $J$ $=6.0 \mathrm{~Hz}, 1 \mathrm{H}, 4-\mathrm{H}), 5.00\left(\mathrm{~s}, 2 \mathrm{H}, 5^{\prime \prime \prime}-\mathrm{H}\right), 5.96\left(\mathrm{~s}, 2 \mathrm{H}, \mathrm{OCH}_{2} \mathrm{O}\right), 6.11\left(\mathrm{~s}, 1 \mathrm{H}, 4^{\prime}-\mathrm{OH}\right), 6.64(\mathrm{~s}$, $\left.2 \mathrm{H}, 2^{\prime}, 6^{\prime \prime}-\mathrm{H}\right), 6.55(\mathrm{~s}, 1 \mathrm{H}, 8-\mathrm{H}), 6.79\left(\mathrm{~d}, J=10.0 \mathrm{~Hz}, 2 \mathrm{H}, 2^{\prime \prime}, 6^{\prime \prime}-\mathrm{H}\right), 6.89$ (s, $\left.1 \mathrm{H}, 5-\mathrm{H}\right)$, 7.35, $7.42\left(\mathrm{~m}\right.$, each $\left.1 \mathrm{H}, 10^{\prime \prime \prime}-\mathrm{H}, 11^{\prime \prime \prime}-\mathrm{H}\right), 7.44\left(\mathrm{~s}, 1 \mathrm{H}, 14^{\prime \prime \prime}-\mathrm{H}\right), 7.46\left(\mathrm{~d}, J=5.5 \mathrm{~Hz}, 2 \mathrm{H}, 3^{\prime \prime}\right.$, $\left.5^{\prime \prime}-\mathrm{H}\right), 7.75\left(\mathrm{~d}, J=9.0 \mathrm{~Hz}, 1 \mathrm{H}, 9^{\prime \prime \prime}-\mathrm{H}\right), 7.98\left(\mathrm{~d}, J=8.5 \mathrm{~Hz}, 1 \mathrm{H}, 12^{\prime \prime \prime}-\mathrm{H}\right), 9.01(\mathrm{~d}, J=8.0 \mathrm{~Hz}$, $1 \mathrm{H}, \mathrm{N}=\mathrm{CH}) .{ }^{13} \mathrm{C} \mathrm{NMR}\left(400 \mathrm{MHz}, \mathrm{CDCl}_{3}\right): \delta 7.48\left(\mathrm{CH}_{3}\right) ; 23.56$ (isopropyl $\left.\mathrm{CH}_{3} \times 2\right) ; 34.12$ $\left(\mathrm{CH}_{2}\right) ; 37.85(\mathrm{CH}) ; 42.65(\mathrm{CH}) ; 44.85(\mathrm{CH}) ; 45.54$ (isopropyl $\mathrm{CH}$ ); 51.60 (camptothecin Cring $\left.\mathrm{CH}_{2}\right) ; 56.56\left(\mathrm{OCH}_{3} \times 2\right) ; 58.27\left(\underline{\mathrm{CH}}_{2} \mathrm{OH}\right) ; 68.92$ (epipodophyllotoxin C-ring $\underline{\mathrm{CHNH}}$ ); 
70.90 (lactone $\left.\mathrm{CH}_{2}\right) ; 95.56$ (- $\left.\mathrm{COH}\right) ; 100.73$ (camptothecin D-ring $\left.\mathrm{CH}\right) ; 101.55\left(\mathrm{OCH}_{2} \mathrm{O}\right)$; 107.38 (epipodophyllotoxin E-ring $\mathrm{CH} \times 2$ ); 110.52 (epipodophyllotoxin $\mathrm{B}$-ring $\mathrm{CH}$ ); 110.52 (epipodophyllotoxin B-ring $\mathrm{CH}$ ); 116.60 (aniline $\mathrm{CH}$ ); 116.82 (aniline $\mathrm{CH}$ ); 123.56 (camptothecin D-ring C); 125.25 (aniline $\mathrm{CH}$ ); 125.58 (camptothecin A-ring $\mathrm{CH}$ ); 125.58 (aniline $\mathrm{CH}$ ); 126.28 (camptothecin A-ring $\mathrm{CH}$ ); 127.85 (quinolone $\mathrm{C}$ ); 128.42 (camptothecin A-ring $\mathrm{CH}$ ); 129.76 (quinolone $\mathrm{C}$ ); 129.28 (camptothecin A-ring $\mathrm{CH}$ ); 130.67 (epipodophyllotoxin B-ring C); 131.37 (epipodophyllotoxin B-ring C); 134.22 (epipodophyllotoxin E-ring C); 134.78 (epipodophyllotoxin E-ring C); 136.81 (aniline C); 136.39 (camptothecin A-ring C); 142.58 (quinolone C); 146.58 (aniline C); 146.65 (camptothecin C-ring C); 147.54 (epipodophyllotoxin B-ring C); 147.54 (epipodophyllotoxin B-ring C); 148.94 (epipodophyllotoxin E-ring C); 149.67 (epipodophyllotoxin E-ring C); 151.37 (camptothecin D-ring C); 152.70 (quinolone C); 154.77 (amide $\mathrm{C}=\mathrm{O}$ ); 161.79 (imine $\mathrm{C}=\mathrm{N}$ )) 173.22 (lactone $\mathrm{C}=\mathrm{O}$ ); 176.35 (amide $\mathrm{C}=\mathrm{O}$ ).; HRMS $(\mathrm{m} / \mathrm{z}): \mathrm{C}_{51} \mathrm{H}_{50} \mathrm{~N}_{5} \mathrm{O}_{11}$ calculated: $908.3501[\mathrm{M}+\mathrm{H}]^{+}$; found: $908.3513[\mathrm{M}+\mathrm{H}]^{+}$.

\subsection{Conjugate 2E}

Red crystalline powder; $\mathrm{mp} 242{ }^{\circ} \mathrm{C}$ (decomp); ESI MS m/z $908.4(\mathrm{M}+1)^{+}$; FT-IR (ATR crystal plate) 3311 (broad, OH, NH), 2968, 2935 (alkyl CH), 1766 (lactone carbonyl), 1649, 1589 (amide carbonyl) $\mathrm{cm}^{-1} ;{ }^{1} \mathrm{H}$ NMR $\left(\mathrm{CDCl}_{3}\right): \delta 1.01\left(\mathrm{t}, J=7.5 \mathrm{~Hz}, 3 \mathrm{H}, 18^{\prime \prime \prime}-\mathrm{H}\right), 1.21$ (d, $\left.J=6.5 \mathrm{~Hz}, 6 \mathrm{H},\left(\mathrm{CH}_{3}\right)_{2}\right), 2.35\left(\mathrm{~m}, 2 \mathrm{H}, 19^{\prime \prime \prime}-\mathrm{H}\right), 3.09(\mathrm{~m}, 1 \mathrm{H}, 3-\mathrm{H}), 3.60(\mathrm{dd}, J=5.5,14.5 \mathrm{~Hz}$, $1 \mathrm{H}, 2-\mathrm{H}), 3.81\left(\mathrm{~s}, 6 \mathrm{H}, \mathrm{OCH}_{3} \times 2\right), 4.08(\mathrm{~m}, 2 \mathrm{H}, 11-\mathrm{H}$ and $\mathrm{NCH}), 4.45(\mathrm{t}, J=8.0 \mathrm{~Hz}, 1 \mathrm{H}, 11-$ $\mathrm{H}), 4.81(\mathrm{~d}, J=5.0 \mathrm{~Hz}, 1 \mathrm{H}, 1-\mathrm{H}), 4.93\left(\mathrm{~s}, 2 \mathrm{H}, 22^{\prime \prime \prime}-\mathrm{H}, 4-\mathrm{H}\right), 5.20\left(\mathrm{~s}, 2 \mathrm{H}, 5^{\prime \prime \prime}-\mathrm{H}\right), 5.82(\mathrm{~s}, 2 \mathrm{H}$, $\left.\mathrm{OCH}_{2} \mathrm{O}\right), 6.41\left(\mathrm{~s}, 2 \mathrm{H}, 2^{\prime}, 6^{\prime}-\mathrm{H}\right), 6.47(\mathrm{~s}, 1 \mathrm{H}, 8-\mathrm{H}), 6.70(\mathrm{~s}, 1 \mathrm{H}, 5-\mathrm{H}), 6.76(\mathrm{~d}, J=8.0 \mathrm{~Hz}$, $\left.1 \mathrm{H}, 2^{\prime \prime}-\mathrm{H}\right), 6.89\left(\mathrm{~m}, 1 \mathrm{H}, 5^{\prime \prime}-\mathrm{H}\right), 7.36\left(\mathrm{~m}, 2 \mathrm{H}, 7.59,3^{\prime \prime}-\mathrm{H}, 4^{\prime \prime}-\mathrm{H}\right), 7.59,7.65(\mathrm{t}, J=8.0 \mathrm{~Hz}$, each $\left.1 \mathrm{H}, 10^{\prime \prime \prime}-\mathrm{H}, 11^{\prime \prime \prime}-\mathrm{H}\right), 7.44\left(\mathrm{~s}, 1 \mathrm{H}, 14^{\prime \prime \prime}-\mathrm{H}\right), 7.99\left(\mathrm{~d}, J=8.5 \mathrm{~Hz}, 1 \mathrm{H}, 9^{\prime \prime \prime}-\mathrm{H}\right), 8.03(\mathrm{~m}$, $\left.1 \mathrm{H}, 14^{\prime \prime \prime}-\mathrm{H}\right), 8.22$ (d, $\left.J=8.5 \mathrm{~Hz}, 1 \mathrm{H}, 12^{\prime \prime \prime}-\mathrm{H}\right), 9.20$ (s, $\left.1 \mathrm{H}, \mathrm{N}=\mathrm{CH}\right) .{ }^{13} \mathrm{C} \mathrm{NMR}(400 \mathrm{MHz}$, $\left.\mathrm{CDCl}_{3}\right)$ : $\delta 7.89\left(\mathrm{CH}_{3}\right) ; 22.76$ (isopropyl $\left.\mathrm{CH}_{3} \times 2\right) ; 32.42\left(\mathrm{CH}_{2}\right) ; 38.91(\mathrm{CH}) ; 41.65(\mathrm{CH})$; $43.85(\mathrm{CH}) ; 46.74$ (isopropyl $\mathrm{CH}) ; 52.50\left(\mathrm{CH}_{2}\right) ; 56.56\left(\mathrm{OCH}_{3} \times 2\right) ; 58.07\left(\underline{\mathrm{CH}}_{2} \mathrm{OH}\right) ; 68.92$ $(\underline{\mathrm{CHNH}}) ; 76.70$ (lactone $\mathrm{CH}_{2}$ ); 99.54 (- $\underline{\mathrm{COH}}$ ); 100.73 (camptothecin D-ring $\mathrm{CH}$ ); 101.55 $\left(\mathrm{OCH}_{2} \mathrm{O}\right.$ ); 108.38 (epipodophyllotoxin E-ring $\mathrm{CH} \times 2$ ); 110.52 (epipodophyllotoxin B-ring $\mathrm{CH}$ ); 110.89 (epipodophyllotoxin B-ring $\mathrm{CH}$ ); 117.80 (aniline $\mathrm{CH}$ ); 122.76 (camptothecin D-ring C); 124.59 (aniline $\mathrm{CH}$ ); 125.25 (aniline $\mathrm{CH}$ ); 125.58 (camptothecin A-ring $\mathrm{CH}$ ); 126.28 (camptothecin A-ring $\mathrm{CH}$ ); 127.85 (quinolone C); 128.28 (aniline $\mathrm{CH}$ ); 129.42 (camptothecin A-ring $\mathrm{CH}$ ); 129.76 (quinolone $\mathrm{C}$ ); 130.26 (camptothecin A-ring $\mathrm{CH}$ ); 130.67 (epipodophyllotoxin B-ring C); 131.37 (epipodophyllotoxin B-ring C); 132.81 (aniline C); 134.22 (epipodophyllotoxin E-ring C); 134.78 (epipodophyllotoxin E-ring C); 137.39 (camptothecin A-ring C); 142.58 (quinolone C); 144.58 (aniline C); 146.65 (camptothecin C-ring C); 147.54 (epipodophyllotoxin B-ring C); 148.36 (epipodophyllotoxin B-ring C); 148.94 (epipodophyllotoxin E-ring C); 149.67 (epipodophyllotoxin E-ring C); 152.37 (camptothecin D-ring C); 152.70 (quinolone $\mathrm{C}$ ); 154.77 (amide $\mathrm{C}=\mathrm{O}$ ); 161.79 (imine $\mathrm{C}=\mathrm{N}-$ ); 173.22 (lactone $\mathrm{C}=\mathrm{O}$ ); 176.35 (amide $\mathrm{C}=\mathrm{O}$ ); $\operatorname{HRMS}(\mathrm{m} / \mathrm{z}): \mathrm{C}_{51} \mathrm{H}_{50} \mathrm{~N}_{5} \mathrm{O}_{11}$ calculated: $908.3501[\mathrm{M}+\mathrm{H}]^{+}$; found: $908.3515[\mathrm{M}+\mathrm{H}]^{+}$.

\subsection{Biology}

5.4.1. Cell lines-The etoposide resistant cell line KB/7D and the CPT-resistant cell line KB CPT 100 were maintained in growth medium supplemented with $7 \mu \mathrm{M}$ of etoposide and $100 \mathrm{nM}$ of CPT, respectively. Revertant KB CPT $100^{\text {rev }}$ cells also were used for studies. All cell lines were maintained in RPMI 1640 medium containing 10\% fetal bovine serum.

5.4.2. Growth inhibition assay-Cells in logarithmic phase were cultured at a density of 5000 cells $/ \mathrm{mL}$ in 24 -well plates. The cells were exposed to various concentrations of drugs for $72 \mathrm{~h}$. The effect on cell growth was evaluated using the ethylene blue dye assay, as 
described previously. ${ }^{22}$ Drug concentrations that inhibited $50 \%$ of cell growth $\left(\mathrm{IC}_{50}\right)$ were determined.

5.4.3. Measurement of protein-linked DNA breaks (PLDBs)-Cells were labeled with $\left[{ }^{14} \mathrm{C}\right]$ thymidine for $24 \mathrm{~h}$. Labeled cells were treated with drugs for one $\mathrm{h}$ before the analysis for PLDBs by potassium-SDS co-precipitation method. ${ }^{35}$

5.4.4. Oligonucleotide cleavage and religation by topoisomerase I-Purified recombinant topoisomerase I was used to study the impact of drugs on the cleavage and religation steps, as described previously. ${ }^{35}$ Briefly, 50 fmols of radiolabled ON5-ON4 oligoduplex (Fig. 3A) was incubated with topoisomerase I $(220 \mathrm{fmol})$ in the presence or absence of drugs at $37^{\circ} \mathrm{C}$ for $15 \mathrm{~min}$ and stopped by adding SDS to final concentration $0.5 \%$. Covalent-linked Topo I was digested by proteinase $\mathrm{K}(1 \mathrm{mg} / \mathrm{mL}$ final concentration) followed by denaturing urea/polyacrylamide gel electrophoresis. The gel was analyzed by autoradiography and PhosphoImaging screen (Molecular Dynamics-Amersham Bioscience, Piscataway, NJ). Religation reaction was started with the suicide cleavage complex generated by cleavage reaction by adding 5 pmol of ON6 (Fig. 4A). The reaction was performed at $37{ }^{\circ} \mathrm{C}$ for $30 \mathrm{~min}$ prior to urea/polycrylamide gel electophoresis.

5.4.5. DNA cleavage by topoisomerase II-Uniquely end-labeled pBR322 DNA, prepared as described previously, ${ }^{22}$ was incubated with topoisomerase II (USB, Cleveland, $\mathrm{OH}$ ) and compounds in $1 \times$ reaction buffer (USB, Cleveland, $\mathrm{OH}$ ) at $37^{\circ} \mathrm{C}$ for $15 \mathrm{~min}$. The reaction was terminated with $1 \%$ SDS and subjected to proteinase $\mathrm{K}$ digestion before gel electrophoresis. The gel was dried and autoradiographed for $48 \mathrm{~h}$.

\section{Acknowledgments}

This work was partly supported by NIH grant CA17625, awarded to K.H.L. and an National Foundation for Cancer Research as well as NIH grants CA63477 and CA154295-01A1 from the National Cancer Institute awarded to Y.C.C. Dr. Cheng is a Fellow of the National Foundation for Cancer Research.

\section{References and notes}

1. Wall ME, Wani MC, Cook CE, Palmer KH, McPhail AT, Sim G. J. Am. Chem. Soc. 1966; 88:3888.

2. Hsiang YH, Hertzberg R, Hecht S, Liu LF. J. Biol. Chem. 1985; 260:14873. [PubMed: 2997227]

3. Wang JC. J. Mol. Biol. 1971; 55:523-533. [PubMed: 4927945]

4. Hsiang YH, Lihou MG, Liu LF. Cancer Res. 1989; 49:5077. [PubMed: 2548710]

5. Johnson PK, McCabe FL, Faucette LF, Hertzberg RP, Kingsbury WD, Boehm JC, Caranfa MJ, Holden KG. Proc. Am. Assoc. Cancer Res. 1989; 30:623.

6. Fukuoka M, Niitani H, Suzuki A, Motomiya M, Hasegawa K, Nishiwaki Y, Kuriyam T, Ariyoshi Y, Negoro S, Masuda N. J. Clin. Oncol. 1992; 10:16. [PubMed: 1309380]

7. Rasheed ZA, Rubin EH. Oncogene. 2003; 22:7296. [PubMed: 14576839]

8. Pavillard V, Kherfellah D, Richard S, Robert J, Montaudon D. British. J. Cancer. 2001; 85:1077.

9. Pommier V. Cancer Chemo. Pharmacol. 1993; 32:103.

10. D'Arpa P, Beardmore C, Liu F. Cancer Res. 1990; 50:6919. [PubMed: 1698546]

11. Bertrand R, O’Conner PM, Kerrigan D, Pommier V. Eur. J. Cancer. 1992; 28:743. [PubMed: 1326304]

12. Denny WA, Baguley BC. Curr. Topics Med. Chem. 2003; 3:1349.

13. Salerno S, Settimo F. Da, Taliani S, Simorini F, Motta C. La, Fornaciari G, Marini AM. Curr. Med. Chem. 2010; 17:4270. [PubMed: 20939813]

14. Perrin D, van Hille B, Barret JM, Kruczynski A, Etievant C, Imtert I, Hill BT. Biochem. Pharmacol. 2000; 59:807. [PubMed: 10718339] 
15. Rao VA, Agama K, Holbeck S, Pommier Y. Cancer Res. 2007; 67:9971. [PubMed: 17942930]

16. Gellert M, Mizuuchi K, O’Dea MH, Nash HA. Proc Natl Acad Sci USA. 1976; 73:3872. [PubMed: 186775]

17. Chen GL, Yang L, Rowe TC, Halligan BD, Tewey KM, Liu LF. J. Biol. Chem. 1984; 259:13560. [PubMed: 6092381]

18. Ross W, Rowe T, Glisson B, Yalowich J, Liu LF. Cancer Res. 1984; 44:5857. [PubMed: 6094001]

19. Zhu XK, Guan J, Tachibana Y, Bastow KF, Cho SJ, Cheng HH, Cheng YC, Gurwith M, Lee KH. J. Med. Chem. 1999; 42:2441. [PubMed: 10395485]

20. Lee, KH.; Xiao, Z. Anticancer Agents from Natural Products. Cragg, GM.; Kingston, D.; Newman, DJ., editors. CRC Press; 2005. p. 71-87.

21. Bastow KF, Wang HK, Cheng YC, Lee KH. Bioorg. Med. Chem. 1997; 5:1481. [PubMed: 9313854]

22. Chang JC, Guo X, Chen HX, Jiang Z, Fu Q, Wang HK, Bastow KF, Zhu XK, Guan J, Lee KH, Cheng YC. Biochem. Pharmacol. 2000; 59:497. [PubMed: 10660116]

23. Adamovics JA, Hutchinson CR. J. Med. Chem. 1979; 22:310. [PubMed: 423214]

24. Hertzberg RP, Caranfa MJ, Holden KG, Jakas DR, Gallaghe,r G, Mattern MR, Mong SM, Bartus JO, Johnson RK, Kingsbury WD. J. Med. Chem. 1989; 32:715. [PubMed: 2537428]

25. Li QY, Zu YG, Shi RZ, Yao LP. Curr. Med. Chem. 2006; 13:2021. [PubMed: 16842195]

26. Fassbery J, Stella VJ. J. Pharm. Sci. 1992; 81:676. [PubMed: 1403703]

27. Burke TG, Mi Z. Anal. Biochem. 1993; 212:285. [PubMed: 8368506]

28. Sawada S, Yaegashi T, Furuta T, Yokokura T, Miyasaka T. Chem. Pharm. Bull. 1993; 41:310. [PubMed: 8500199]

29. Park SY, Lam W, Cheng YC. Cancer Res. 2002; 62:459. [PubMed: 11809696]

30. Rowe TC, Chen GL, Hsiang YH, Liu LF. Cancer Res. 1986; 46:2021. [PubMed: 3004716]

31. Park SY, Cheng YC. Cancer Res. 2005; 65:3894. [PubMed: 15867389]

32. Lansiaux A, Léonce S, Kraus-Berthier L, Bal-Mahieu C, Mazinghien R, Didier S, DavidCordonnier MH, Hautefaye P, Lavielle G, Bailly C, Hickman JA, Pierré A. Mol. Pharmacol. 2007; 72:311. [PubMed: 17494837]

33. Crugeiras J, Rios A, Riveiros E, Richard JP. J. Am. Chem. Soc. 2009; 13:15815. [PubMed: 19807092]

34. Lipinski CA, Lombardo F, Bominy BW, Feeney PJ. Advanced Drug Delivery Res. 2001; 46:3.

35. Montecucco A, Pedrali-Noy G, Spadari S, Zanolin E, Ciarrocchi G. Nucleic Acids Res. 1988; 16:3907. [PubMed: 3287337] 

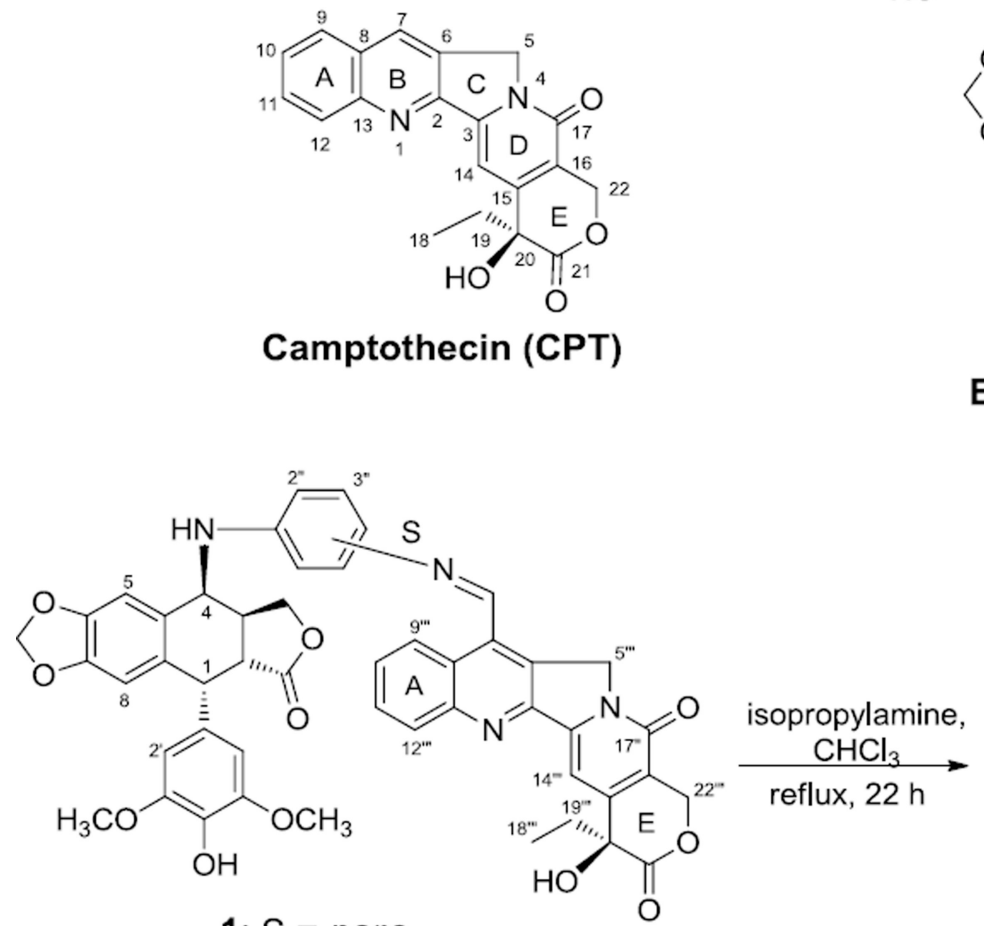

1: $\mathrm{S}=$ para-

2: $\mathrm{S}=$ ortho-

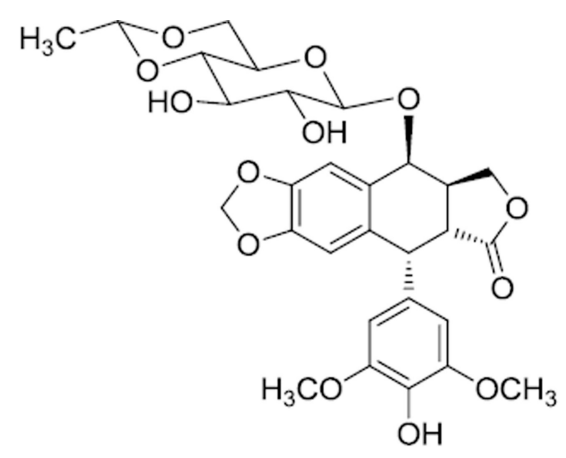

\section{Etoposide (VP-16)}

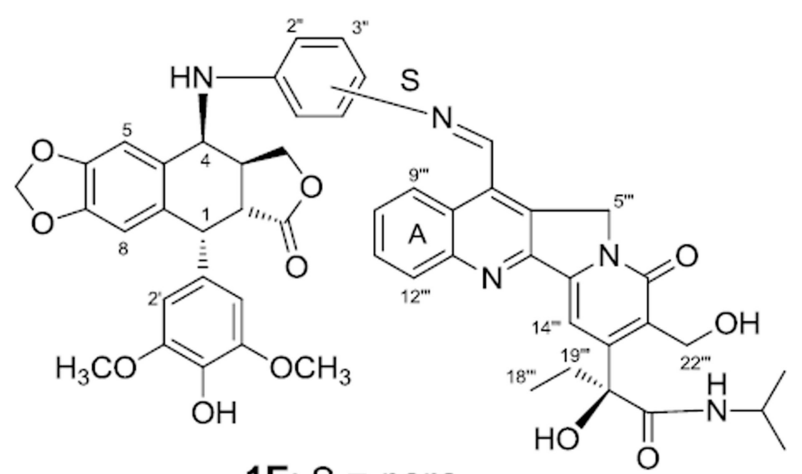

$1 \mathrm{E}: \mathrm{S}=$ para-

2E: $\mathrm{S}=$ ortho-

Figure 1.

Structures of CPT, etoposide, and CPT-epipodophyllotoxin conjugates. 


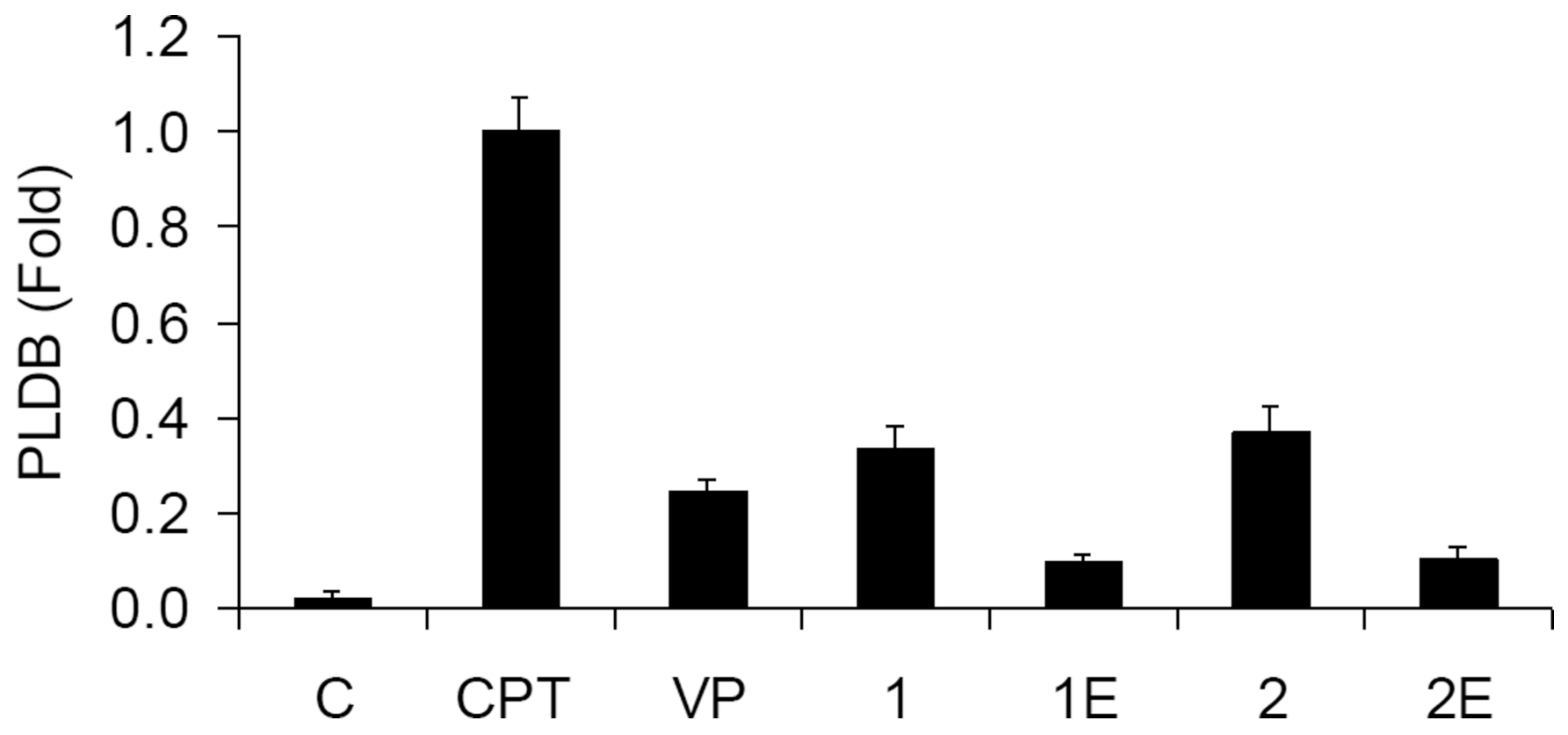

Figure 2.

Induction of PLDB. $\left[{ }^{14} \mathrm{C}\right]$-Thymidine -labeled $\mathrm{KB}$ cells were incubated with $2.5 \mu \mathrm{M}$ of the indicated compounds at $37^{\circ} \mathrm{C}$ for one hour. PLDB was analyzed by the potassium/SDS method as described. 
(A)

ON5 $\quad{ }^{32} \mathrm{P}-\mathrm{GAAAAAAGACTTGG}$

(B)

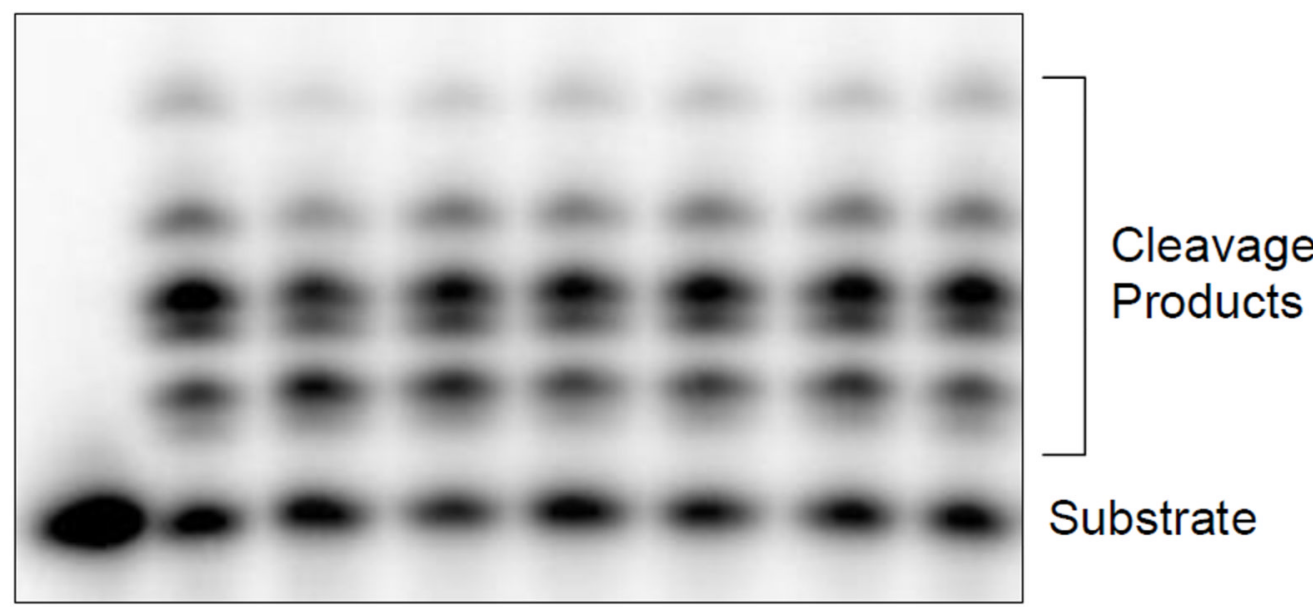

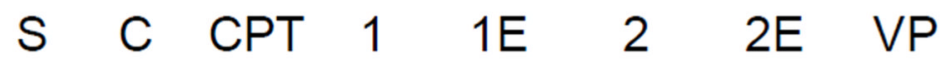

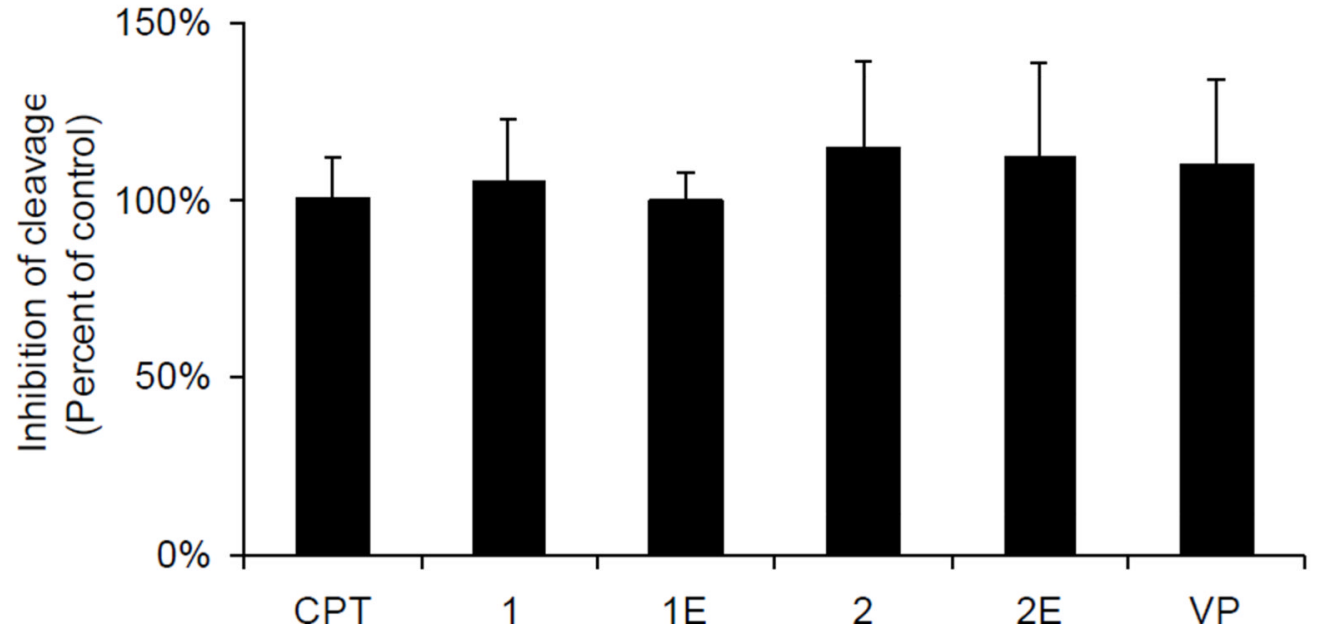

Figure 3.

Impact of CPT-epipodophyllotoxin conjugates on topoisomerase I cleavage activity. (A). Schematic diagram of the cleavage assay. (B). $\left[\gamma^{32} \mathrm{P}\right]$-ATP-labeled ON4/ON5 was incubated with topoisomerase I and indicated compounds $(25 \mu \mathrm{M})$ at $37^{\circ} \mathrm{C}$ for $15 \mathrm{~min}$. Covalentlinked topoisomerase I was digested by proteinase $\mathrm{K}$ and the cleavage products (containing topoisomerase I amino acid residues on the $3^{\prime}$ end of the cleaved strand) were separated by $20 \%$ denaturing urea/polyacrylamide gel electrophoresis. 


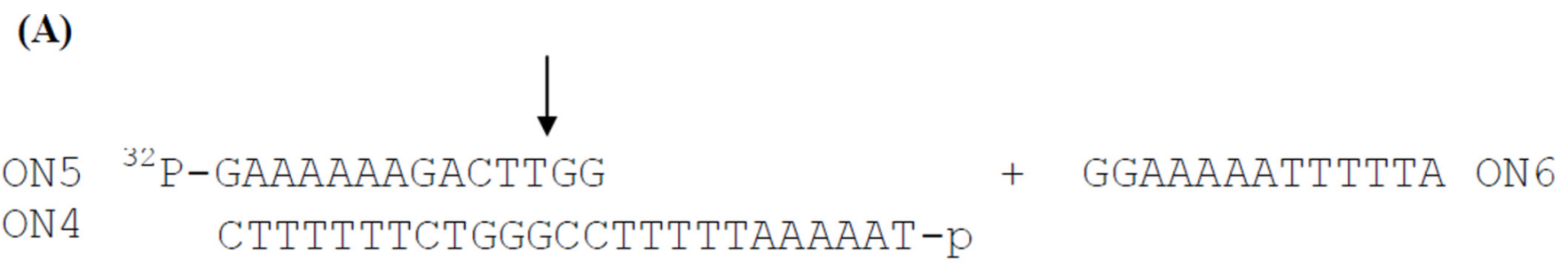

(B)
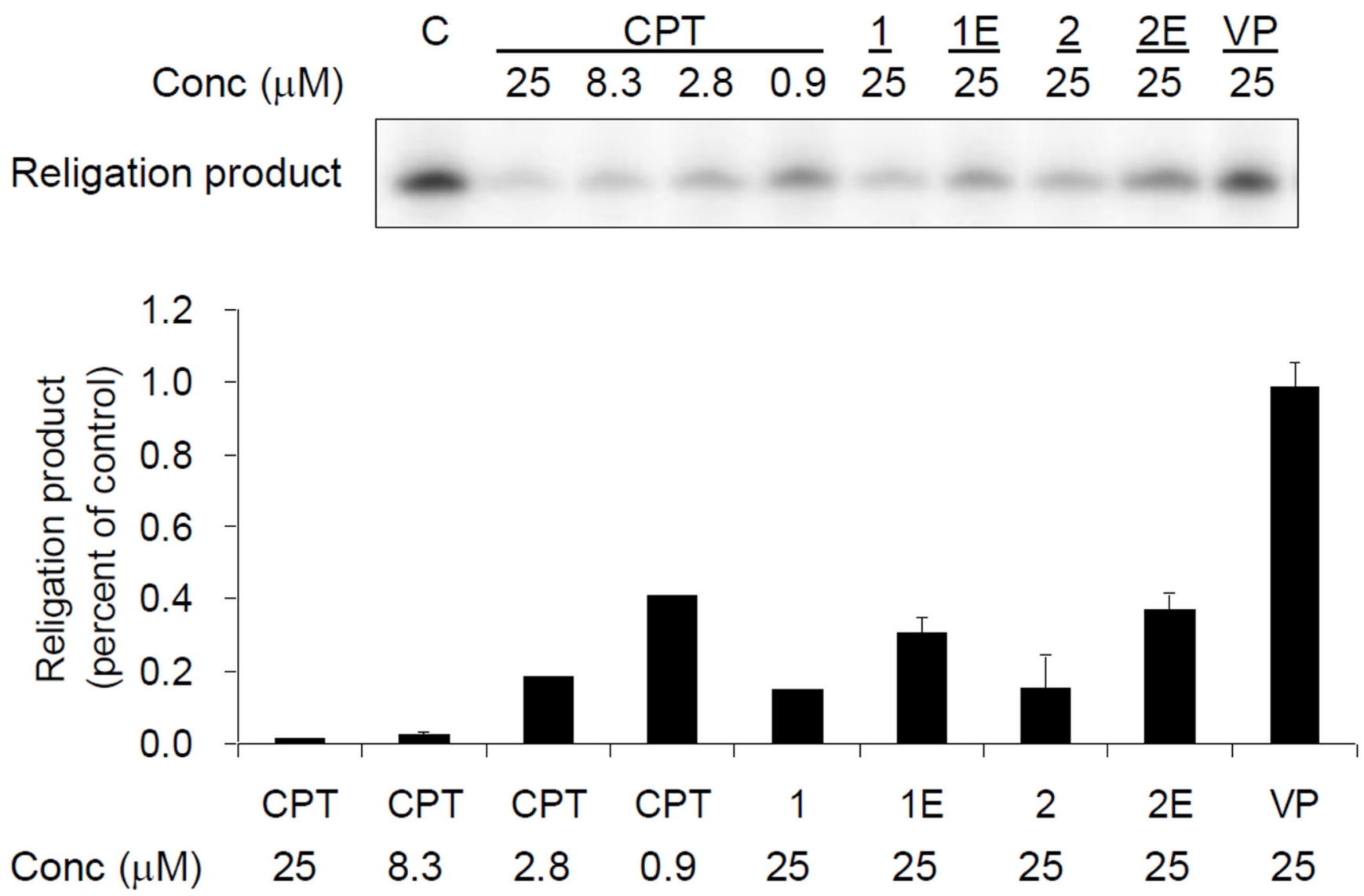

Figure 4.

Inhibition of TLD religation by CPT-epipodophyllotoxin conjugates. (A). Schematic diagram of the religation assay. (B). Religation was done by incubating 5 pmol of ON6 to the suicide cleavage complex in the presence of indicated compounds at $37^{\circ} \mathrm{C}$ for min. Samples were analyzed by $20 \%$ urea/polyacrylamide gel electrophoresis and quantified by phosphoimager.. 

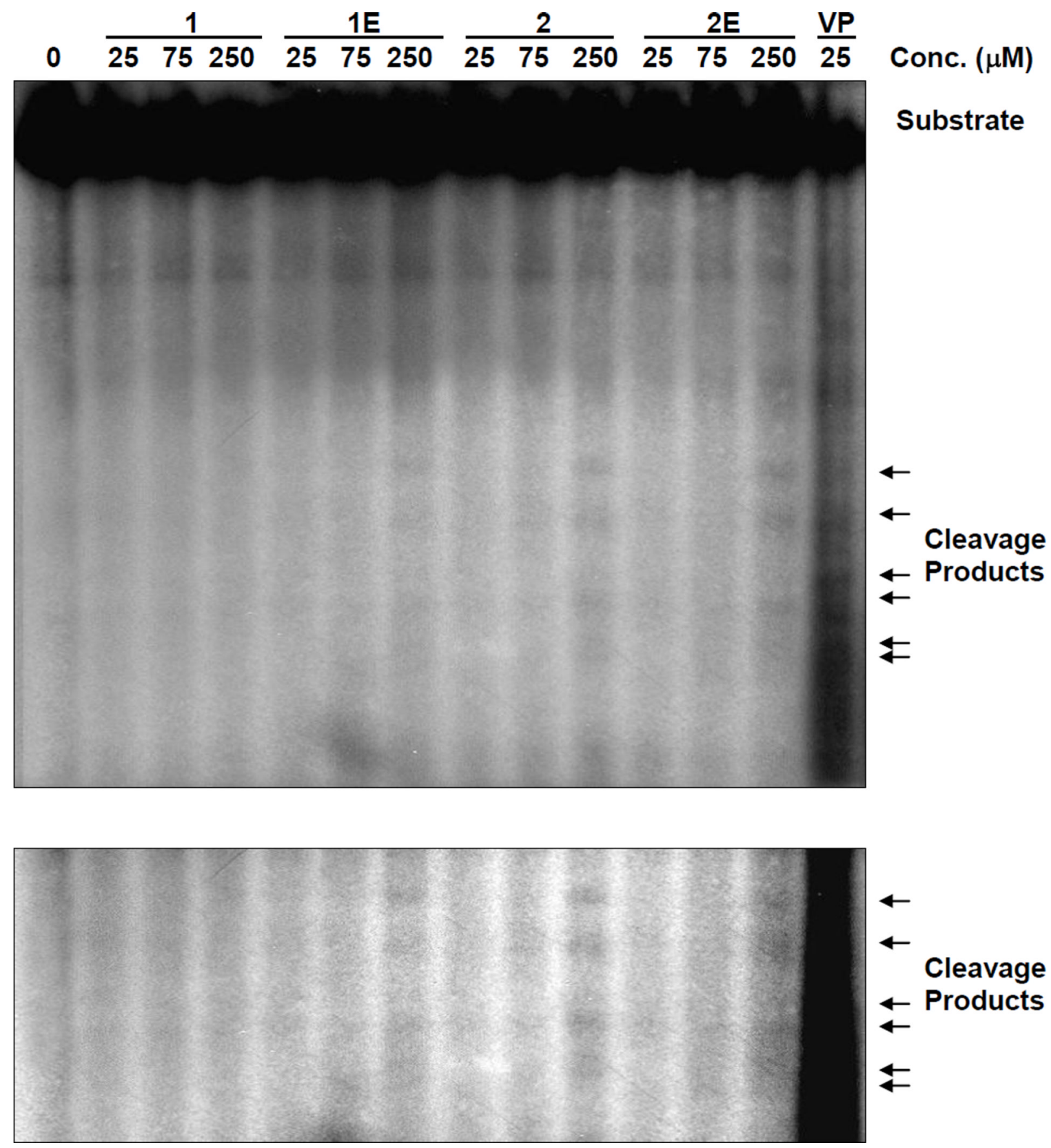

Figure 5.

The impact of CPT-epipodophyllotoxin conjugates on topoisomerase II-induced DNA cleavage. Linearized and $\left[\mathrm{a}^{-}{ }^{32} \mathrm{P}\right] \mathrm{dCTP}-\mathrm{labeled} \mathrm{pBR} 322$ was incubated with $10 \mathrm{U}$ topoisomerase II and the indicated compounds at $37{ }^{\circ} \mathrm{C}$ for $30 \mathrm{~min}$. Samples were proteinase $\mathrm{K}$-treated, substrates and cleavage products (as indicated with arrows) were electrophoresed in $1.5 \%$ agarose gel and detected by autoradiography. The same figure with higher contrast is shown in the lower panel. 


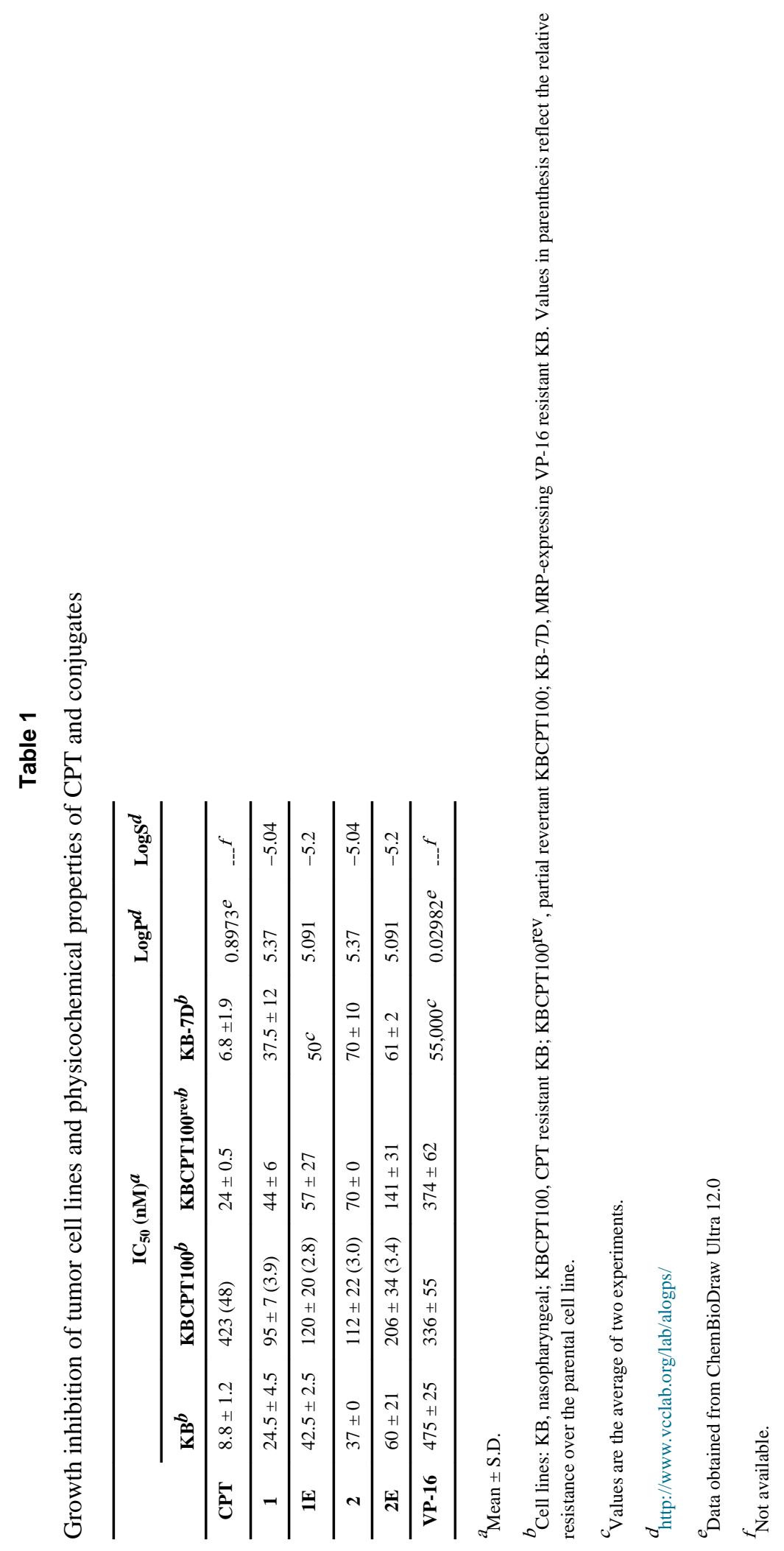

